\title{
A comparison of the volatile and phenolic compositions of Muscat of Bornova wines from two different terroirs in the Aegean region of Turkey
}

\author{
Selin YABACI KARAOĞLAN ${ }^{1 *}$ (D), Turgut CABAROĞLU²
}

\begin{abstract}
This study investigated the aromatic and phenolic compositions of two different Muscat of Bornova wines from two distinct terroirs (İzmir and Manisa) and compared them to basic terroir properties over the course of two consecutive years. The 53 volatile and 14 phenolic compounds found, were identified and quantified by GC-MS-FID and HPLC-DAD with MS, respectively. The Menderes terroir has higher amounts of terpene and C6 compounds which are varietal aroma compounds. The total phenolic content in the Menderes terroir is higher than in the Kemaliye terroir. Trans-caftaric acid was the most abundant phenolic compound According to the statistical results, most of the compounds were affected by both vintage and terroir; however, the effect of vintage seems to be more significant.
\end{abstract}

Keywords: Muscat of Bornova; muscat wine; phenolics; terroir; volatiles.

Practical Application: Comparing main composition of Muscat of Bornova wines from two different vineyards in two consecutive years by associating with climate and distinct terroir characteristics.

\section{Introduction}

Muscat of Bornova is an indigenous aromatic white wine grape (Vitis vinifera) grown on the Aegean side of Turkey, mostly in the Izmir and Manisa subregions. The Menderes terroir has a warm climate and its name comes from the river Menderes, which meanders down to the Aegean Sea ( $82 \mathrm{~m}$ above sea level). Kemaliye is a transitional area between the Mediterranean and continental climate features in higher land (245 $\mathrm{m}$ above sea level). The Muscat of Bornova grape variety produces one of the premium aromatic white wines of Turkey (Selli et al., 2006).

The grape producing the original aroma of Muscat wines is as a result of the presence of terpenes (Delcroix et al., 1994) especially linalool, geraniol, nerol, citronellol and a-terpineol (Bordiga et al., 2013; Campo et al., 2005; Radeka et al., 2008; Styger et al., 2011) and norisoprenoids (Vilanova et al., 2007). In the wine aroma development, the terroir has been known as an important factor. The term covers the vine and its physical environment (geography, soil and climate) as well as their interactions (Seguin, 1986; Seguin, 1988; Van Leeuwen et al., 2010). This aspect is entirely new for Turkish winemaking. Environmental influences on the main composition of Muscat of Bornova wines have not yet been studied.

The present research analyzes the composition of Muscat of Bornova wines grown in the east and west of the Aegean region (Menderes/Izzmir and Kemaliye/Manisa sub-regions), to understand the terroir effect.

\section{Materials and methods}

\subsection{Vineyards and the grape samples}

This study was performed in two different terroirs and for two vintages (2012 to 2013). Production of Muscat of Bornova wines was carried out in the winery of a commercial cellar. Locations of studied terroirs (vineyards) can be seen in Figure 1.

All cultivation techniques were the same for both vineyards. Wine production used Muscat of Bornova grapes from the selected areas Healthy cv. Muscat of Bornova grapes were manually harvested in the first two weeks of August at both vineyards (the harvest dates were 13.08.12 and 18.08.13 for Menderes, 6.08 .12 and 10.08.13 for Kemaliye). Standard white wine production method with minimal skin contact was adopted (Selli et al., 2006). The wines were bottled and stored at $15^{\circ} \mathrm{C}$ for four months prior to analysis.

General and meteorological properties of the studied vineyards are given in Supplemental File 1 (Supplementary Material). In the Menderes terroir, the reported annual precipitation and temperature values (maximum, minimum and average temperatures) were higher than normal for both vintages, especially in 2013 vintage. In Menderes terroir, the reported rainfall was distributed through the whole year at expected times in both vintages, however, in Kemaliye terroir, unexpected rainfalls were reported in June, July and August 2013.

\subsection{Soil analysis}

The samples for soil analysis were obtained from the center of subplots at depths of 30 and $60 \mathrm{~cm}$ at the onset of ripening of the vines (the end of July). The Bouyoucos hydrometer method

${ }^{1}$ Department of Food Engineering, Faculty of Engineering, Adana Alparslan Türkeş Science and Technology University, Sarıçam, Adana, Turkey

${ }^{2}$ Department of Food Engineering, Faculty of Agriculture, University of Çukurova, Adana, Turkey

*Corresponding author: syabaci@atu.edu.tr 


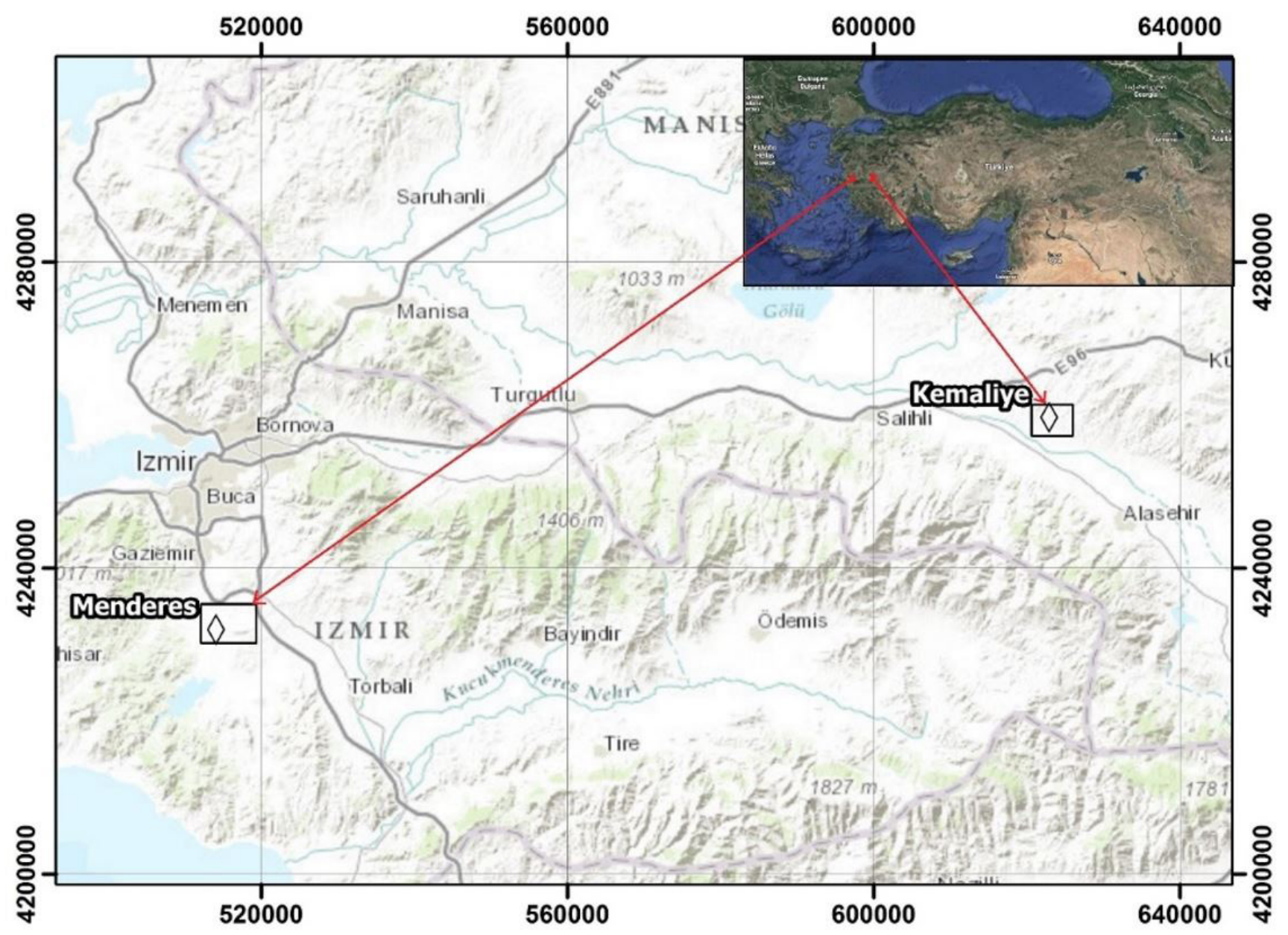

Figure 1. Locations of studied terroirs (vineyards).

was used for the determination of particle size distribution (Bouyoucos, 1962). Microelement analysis (Fe vs. Zn) was tested with an automatic absorption spectrophotometer. For this analysis, soil samples were prepared with extraction solution diethylenetriamine pentaacetic acid (DTPA) and measured according to the method by Lindsay \& Norvell (1978). The Olsen \& Sommers (1982) method was used for the total P analysis. For $\mathrm{K}, \mathrm{Ca}$ and $\mathrm{Mg}$ extraction, $1 \mathrm{~N}$ of ammonium acetate was used $(\mathrm{pH}=7)$ using the Lindsay \& Norvell method (1978). An automatic absorption spectrophotometer was used for the analysis of extracts. Total salt percentage and $\mathrm{pH}$ was measured with a Wheatstone bridge and a $\mathrm{pH}$ meter in saturation mode (Olsen \& Sommers, 1982).

\subsection{Technological parameters of the wines}

In the grapes, brix, titratable acidity, $\mathrm{pH}$ and reducing sugar were measured. In the wines, the alcohol percentage, total acidity, $\mathrm{pH}$, reducing sugar, volatile acidity, dry matter, free and total $\mathrm{SO}_{2}$ and color were analyzed (International Organisation of Vine and Wine, 2016; Ough \& Amerine, 1988). The evaluation of wine colors was performed by a Hunter Lab colorimeter (McGuire, 1992; Wyszecki \& Stiles, 1982).

\subsection{Volatile compound analysis}

For volatile compound analysis, the liquid-liquid extraction method used. The solvent used for the extraction of wines was dichloromethane $\left(\mathrm{CH}_{2} \mathrm{Cl}_{2}\right)$. The volatile concentration of samples was measured as a 4-nonanol equivalent Each sample's aroma extraction was performed in triplicate using an Agilent 6890 N-5973 N Gas Chromatography - Flame Ionization Detector (GC-FID) and Gas chromatography-mass spectrometry (GC-MS) system. In the analysis, a J\&W fused silica DB-wax capillary column ( $60 \mathrm{~m}, 0.25 \mathrm{ID}, 0.25 \mu \mathrm{m}$ film) was used. The details of the analysis and the conditions of the instrument are described in Celik et al. (2015). The volatile compounds were identified by comparing their retention index and their mass spectra on the DB-Wax column with those of a commercial spectra database (Wiley 6, NBS 75k) and against the instrument's internal library created from previous laboratory studies. Some of the identifications were confirmed by the injection of chemical standards into the GC-MS system. Retention indices of the compounds were calculated by using an n-alkane series. 


\subsection{Phenolic compounds analysis}

Samples were directly filtered through a $0.45 \mathrm{~mm}$ nylon filter and injected into the Agilent 1100 High-performance liquid chromatography (HPLC) system coupled with a diode array detector (DAD) (Agilent Technologies, Palo Alto CA-USA). A Phenomenex C18 reversed-phase column $(4.6 \mathrm{~mm} \times 250 \mathrm{~mm}, 5 \mu \mathrm{m})$ (Torrance, CA) was used for the analysis. The identification of the phenolic compounds was made by comparing their retention times and UV spectra to reference standard. Furthermore, the results were confirmed by an Agilent 6430 liquid chromatography coupled with a tandem mass spectrometer (LC-MS/MS) and an electrospray ionization source. The HPLC analysis (determination-quantification) of the main phenolics were performed following the method by Kelebek et al. (2011). External standard calibration curves were used for each compound's quantification in triplicate (ranging from 1 to $200 \mathrm{mg} / \mathrm{L}$ ). The calibration curves and response factors of a structurally closer compound were used for the non-commercial compound quantification, such as procyanidin $\mathrm{B} 1$ for the procyanidin $\mathrm{B} 3$ and $\mathrm{B} 4$, caffeic acid for cis and trans-caftaric acids and p-coumaric acid for cis and trans-coutaric acids. The LC-MS/MS analysis was carried out with the following optimized conditions: capillary voltage $-3 \mathrm{~V}$, capillary temperature $400{ }^{\circ} \mathrm{C}$, desolvation gas flow $1 \mathrm{~L} / \mathrm{min}$, nebulizer gas flow $1.75 \mathrm{~L} / \mathrm{min}$, and spray voltage $5 \mathrm{kV}$. Negative ion mode was used for the analysis.

\subsection{Statistical analysis}

The results were compared using analysis of variance (ANOVA) and Principal Component Analysis (PCA) with XLSTAT statistical software (2015, Addinsoft, New York, USA).
PCA tests were used to determine the significance of differences between regions and years.

\section{Results and discussion}

\subsection{The soil properties of vineyards}

The full list of soil analysis results of the vineyards are given in Supplemental File 2. There are some distinct differences in the amounts of potassium (Menderes, 3.5- Kemaliye $2.5 \mathrm{mg} / \mathrm{kg}$ ), iron (Menderes 8.6- Kemaliye $1.9 \mathrm{mg} / \mathrm{kg}$ ), copper (Menderes 1.9- Kemaliye $0.4 \mathrm{mg} / \mathrm{kg}$ ) and lime (Menderes 10.7\%- Kemaliye 32.2\%). These compounds are higher in the Menderes vineyard. Higher levels of metal ions can influence the rate of enzymatic browning, thus the color of the must and the wine. (Provenzano et al., 2010). Kemaliye features a fairly high lime content compared to Menderes. According to published literature, such lime-rich soils have a tendency to produce "good quality wines" with better aroma intensity, color and body (White et al., 2007).

\subsection{Technological parameters of the Muscat of Bornova grapes and wines}

The general composition analysis results of matured grapes and wines from both terroirs in the 2012 and 2013 vintages were given in Table 1 . In both vintages, sugar contents of grapes (brix, reducing sugar) and therefore the alcohol percentage of wines by volume was higher in Menderes. Higher temperatures, lower altitudes, soil properties - especially fertility (nitrogen, potassium and calcium concentrations- can be related to the sugar content of Menderes terroir grapes (Wang et al., 2015). For both vintages, total acidity of the wines in Kemaliye were higher (average $7.6 \mathrm{~g} / \mathrm{L}$ ) than the Menderes terroir (about $6 \mathrm{~g} / \mathrm{L}$ ).

Table 1. General properties of Muscat of Bornova grapes and wines from both terroirs in two vintages.

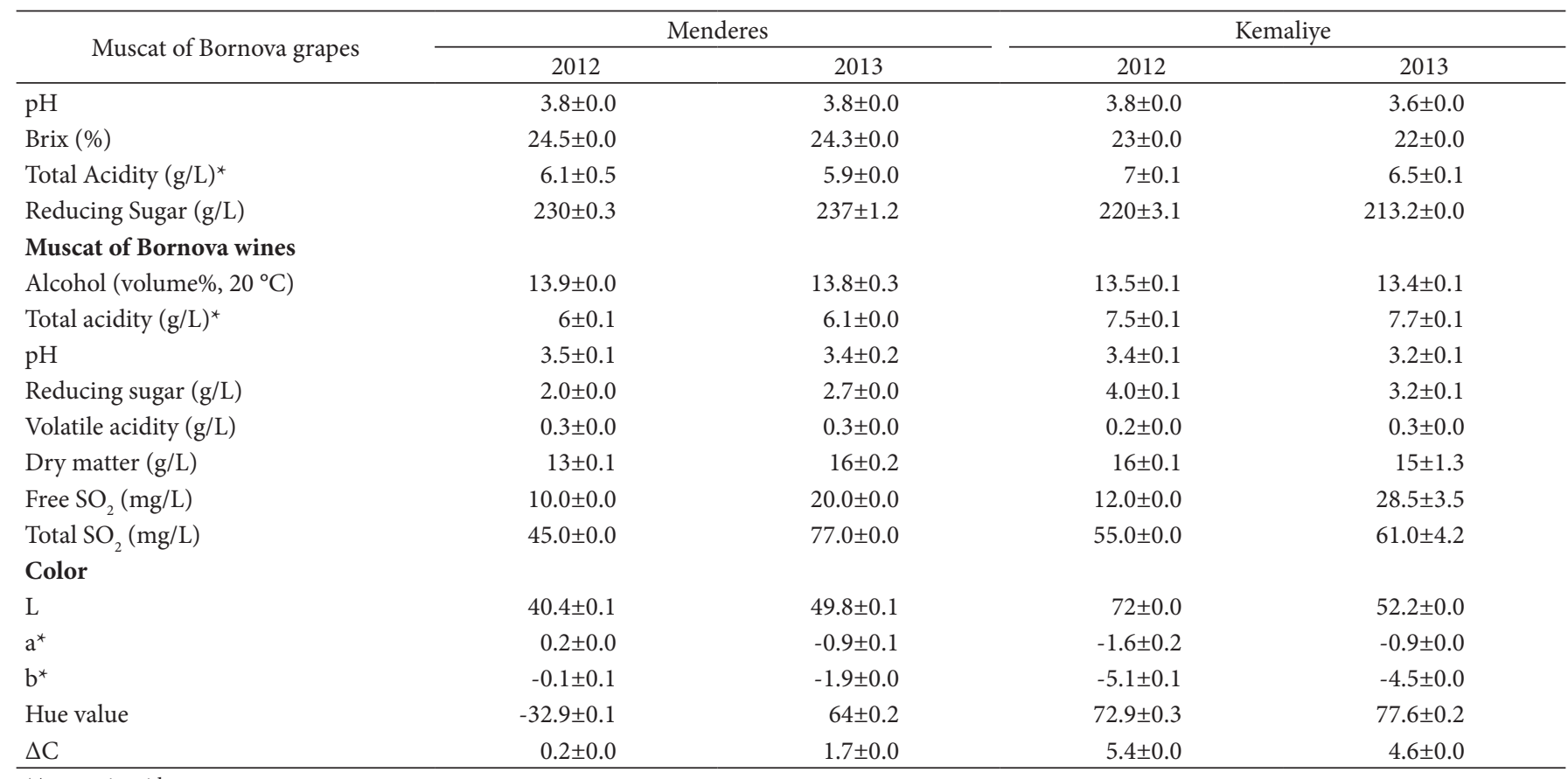

${ }^{\star}$ As tartaric acid. 
As in the case of Kemaliye ( $245 \mathrm{~m}$ above sea level) with higher acidity, higher altitude grapes tend to be more acidic. Another factor that is known to affect acidity is the difference between the day and night time temperature (Jackson \& Lombard, 1993).

Among the colorimetric values, the $\mathrm{L}$ value shows the approximate measure of lightness, and $\mathrm{a}^{\star}$ and $\mathrm{b}^{*}$ coordinates represent the red-green color and yellow-blue color respectively. The $\mathrm{a}^{\star}$ value was very similar in Menderes and Kemaliye, with a negative value representing a green color. Only Menderes 2012 wine showed a positive value which represents a red color. The $b^{\star}$ value which represents blue color in negative values was higher in Kemaliye (-5.1 and -4.5 for 2012 and 2013 vintages). $\mathrm{C}^{\star}$ (Chroma), which is considered a quantitative attribute of colorfulness was again higher in Kemaliye (5.4 and 4.6 for 2012 and 2013 vintages). The Hue value, which represents the qualitative attribute of the color, was higher in Kemaliye. In respect of wine color, the wines both have a light-yellow color, but Kemaliye wines have a blue-green hue. As an exception, the 2012 Menderes wine had a red tone, which can be a mark of its tendency towards browning. The number of metal ions, such as $\mathrm{Fe}$ and $\mathrm{Cu}$, is higher in the soil of Menderes. These ions can accelerate and catalyze the enzymatic browning reactions. In addition to these factors, the color of the wine is also related to the amount and diversity of phenolic compounds.

\subsection{Volatile compounds of Muscat of Bornova wines}

Full list of identified volatile compounds of Muscat of Bornova wines from two vintages, expressed by their means (in $\mu \mathrm{g} / \mathrm{L}$ ) from the three analytical replicates are given in Supplemental File 3 . In the studied terroirs, 53 volatile compounds were identified and quantified. Higher alcohols, volatile acids, esters and terpenes are the compounds most represented in terms of numbers. Terpenes are the most important group in Muscat varieties. The total identified amount of terpene compounds for the Menderes terroir was 1019 and $1525 \mu \mathrm{g} / \mathrm{L}$. For the Kemaliye terroir it was 692 to $1474 \mu \mathrm{g} / \mathrm{L}$ in the 2012 and 2013 vintages, respectively. In relation to regional meteorological data, the annual rainfall and temperatures (Tmin, Tmax and Tavg) were higher in the 2013 vintages for both terroirs, which could have affected the total number of terpenes (higher in 2013 for both terroirs). Even though statistically these compounds were affected by both vintage and terroir, the effect of vintage was more influential. Some important terpenes were significantly affected by the vintage, such as (E)-furan linalool oxide, hotrienol, 3,7-dimethyl-1,5-octadiene-3,7-diol, whereas (E)-pyran linalool oxide and geranic acid were detected in both terroirs in the 2012 vintages.

The amount of linalool within the total terpene compounds of Muscat of Bornova wines is remarkable for the two vintages. This compound is also known as the most abundant compound in Muscat wines (Del Caro et al., 2012). The linalool concentration was quantified for the 2012 and 2013 vintages in the Menderes terroir at 748 and $470 \mu \mathrm{g} / \mathrm{L}$, and 423 and $540 \mu \mathrm{g} / \mathrm{L}$ in the Kemaliye terroir, respectively. These values were found to be higher than the reported threshold value of $15 \mu \mathrm{g} / \mathrm{L}$ in Muscat wines (Guth, 1997) in both terroirs and vintages. Another important terpene, geraniol - with an odor perception threshold of $30 \mu \mathrm{g} / \mathrm{L}$ according to Guth (1997) - was found to be about $50 \mu \mathrm{g} / \mathrm{L}$ in both vintages and terroirs. Geranic acid, which is only found in wines belonging to the 2013 vintage, were also present in a significant amount in Muscat of Bornova wines (2013 Menderes $220 \mu \mathrm{g} / \mathrm{L}$ and 2013 Kemaliye $150 \mu \mathrm{g} / \mathrm{L})$. In particular, Kemaliye wines have a higher concentration of citronellol, hotrienol and a-terpineol than Menderes wines, and this feature can influence the complexity of Kemaliye wines. Citronellol, the odor perception threshold of which is $18 \mu \mathrm{g} / \mathrm{L}$, according to Boidron (1978), could not be detected in 2012 and was found to be 44.5 and $56.4 \mu \mathrm{g} / \mathrm{L}$ in Menderes and Kemaliye in 2013, respectively. It could have a role in the floral and orange blossom flavor of Muscat of Bornova wines from the 2013 vintage. In 2013 vintage samples, Hotrienol was found to be 83.4 and $214.5 \mu \mathrm{g} / \mathrm{L}$ for Menderes and Kemaliye wines, respectively. Hotrienol's threshold value is known to be $110 \mu \mathrm{g} / \mathrm{L}$ (Simpson, 1979), and in this regard, it should have contributed to the linden (lime blossom) smell of wines from Kemaliye in 2013. With its higher threshold value, a-terpineol (250 $\mu \mathrm{g} / \mathrm{L}$; Ferreira et al., 2000) has a floral odor and found to be in higher values in 2013 than 2012 vintages. Although concentrations of these monoterpenes in Muscat of Bornova wines do not exceed their odor perception thresholds, they positively contribute to the wine aroma because of their synergistic and cumulative influence (Radeka et al., 2008). Statistically, except for (E)-pyran linalool oxide and geranic acid concentrations, the terroir effect on the concentrations of all terpene compounds was found to be significant $(\mathrm{p}<0.05)$. The effect of vintage on all terpene compounds was also found to be significant $(\mathrm{p}<0.05)$. About fifteen oxidized and hydroxylated forms of the main monoterpene alcohols have been identified in grape varieties of a Muscat character. Among oxidized terpenes, 2,6-dimethyl-3,7-octadiene-2,6-diol has a significant concentration in Muscat of Bornova wines. In Menderes a wide variation in 2,6-dimethyl-3,7-octadiene-2,6-diol was detected at $84 \mu \mathrm{g} / \mathrm{L}$ and $258 \mu \mathrm{g} / \mathrm{L}$ for 2012 and 2013, respectively. In Kemaliye the amounts were closer at 70 and $45 \mu \mathrm{g} / \mathrm{L}$ for 2012 and 2013, respectively. Although the sensory effects of such oxidized terpenes are low, they can be transformed to monoterpenols by hydrolysis in acidic $\mathrm{pH}$ conditions during vinification or storage (Strauss et al., 1986).

Muscat of Bornova wines, for both vintages, the most abundant aromatic group was the higher alcohols. Higher alcohols are the by-products of alcohol fermentation and have an important contribution to the wine aroma. Some of the most important reported higher alcohols are 2-methyl propanol (isobutyl alcohol), 3-methyl butanol (isoamyl alcohol) 2- methyl butanol, 2-phenyl ethanol and n-propanol (Nykänen \& Suomalainen, 1983). With its characteristic caramel, peach and sweet tones, 1-propanol was found to be present at 1805 to $1834.3 \mu \mathrm{g} / \mathrm{L}$ for Menderes vintages and at 1439.5 to $1239.3 \mu \mathrm{g} / \mathrm{L}$ for Kemaliye vintages in 2012 and 2013, respectively (Nykänen \& Suomalainen, 1983). Isoamyl alcohol is a fruity flavored primary higher alcohol (Fukuda et al., 1990) and its concentration was found to be between 30 and $60 \mathrm{mg} / \mathrm{L}$ in Muscat of Bornova wines. Another important higher alcohol, 2-phenyl ethanol, contributes to the wine aroma with rose tones (Styger et al., 2011) was found to be 6 and $10 \mathrm{mg} / \mathrm{L}$ in Muscat of Bornova wines for 2012 and 2013 respectively, and 11.5 and $12.8 \mathrm{mg} / \mathrm{L}$ in Kemaliye. It was found that the effect of 
terroir on higher alcohols is statistically significant, except for 4-hydroxybenzene ethanol ( $\mathrm{p}<0.05)$. Also, it is seen that the effect of vintage is statistically significant on all higher alcohols.

Esters are secondary products formed during the ethyl alcohol fermentation by yeast, and they gives fruity tones to the wine (Ribéreau-Gayon et al., 2006). Isoamyl acetate was the most abundant compound among the esters in Muscat of Bornova wines (3418 to $4536 \mu \mathrm{g} / \mathrm{L}$ in Menderes, and 2674 to $2154 \mu \mathrm{g} / \mathrm{L}$ in Kemaliye, for 2012 and 2013 respectively). Some important esters were significantly affected by vintages such as ethyl hydrogen succinate, ethyl lactate, ethyl-3-hydroxybutyrate, phenyl ethyl acetate, ethyl laurate, diethyl hydroxbutanoate, ethyl butanoate, hexyl acetate, ethyl 2-hydroxy-propanoate, ethyl 4-hydroxybutanoate and ethyl-2-hydroxy-3-phenylpropanoate. According to statistical evaluations, the effect of vintage on esters was found to be significant except for isoamyl acetate.

Lactones with their "coconut-like, fruity smell" were prominent compounds in the form of $\gamma$-butyrolactone. Most of the lactones form as a result of yeast activities. These $\gamma$-lactones are the most important lactones and are often found in wines (Varnam \& Sutherland, 1994). The effect of vintage and terroir on lactone and ketone concentration was statistically significant; however, the effect of the harvest year on $\gamma$-butyrolactone concentration was not statistically significant, but terroir was. Kemaliye wines had a higher $\gamma$-butyrolactone amount in both vintages. With their high threshold values, fatty acids exhibit a meager contribution to the wine aroma (Del Caro et al., 2012).

Further trace amounts of compounds were non-terpen diols, volatile phenols, ketones, lactones and C6 compounds. The Principal Component Analysis of volatile compounds of Muscat of Bornova wines is shown in Figure 2. The results of Principal Component Analysis with a total variance of $82.81 \%$ are explained by two components, which are F1 59.92\% and F2 22.89\%. According to the F1 component, Muscat of Bornova wines was separated by terroir into different analytical areas (as the upper side and lower side of the $\mathrm{x}$-axis). Because wine samples fell into different analytical areas, the effect of vintage is more important than the effect of the terroir in the Muscat of Bornova samples. Isoamyl acetate, geraniol and linalool seem to be more closely related to the Menderes terroir, while ethyl hexanoate and octanoate, 2-phenyl ethanol and $\gamma$-butyrolactone seem to be more related to the Kemaliye terroir.

\subsection{Phenolic compounds of Muscat of Bornova wines}

The phenolic compounds of Muscat of Bornova wines from the two vintages, expressed by their means (in $\mu \mathrm{g} / \mathrm{L}$ ) for the three analytical replicates, are given in Table 2. Eight phenolic acids, 5 flavanols and a flavonol were identified and quantified in Muscat of Bornova wines. Wines from the Menderes terroir had a slightly higher amount of phenolic compounds (as a total

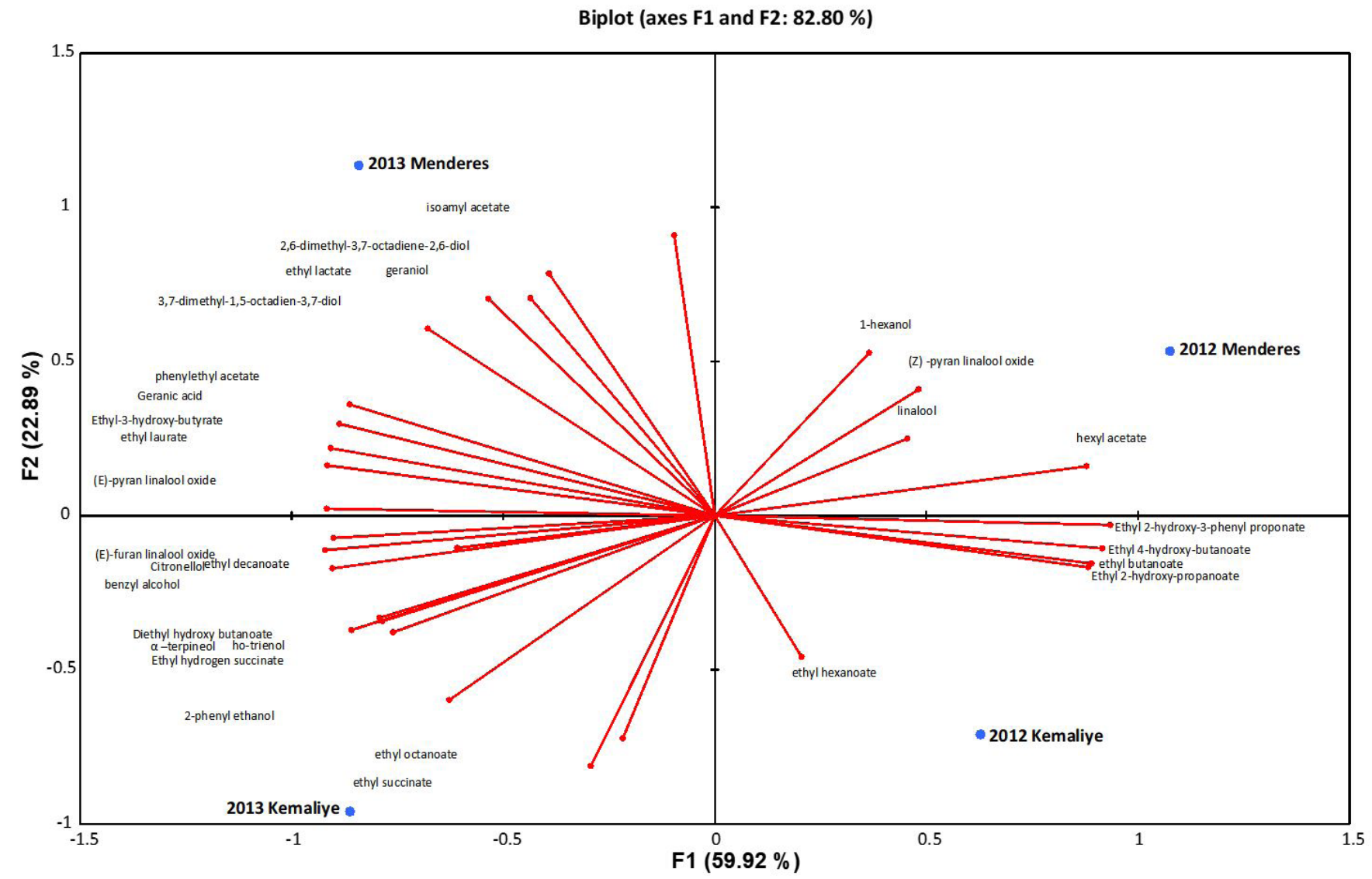

Figure 2. Principal component analysis of important volatile compounds of Muscat of Bornova wines. 
Table 2. Identified phenolic compounds of Muscat of Bornova wines from both terroirs in two vintages ( $\mu \mathrm{g} / \mathrm{L})$.

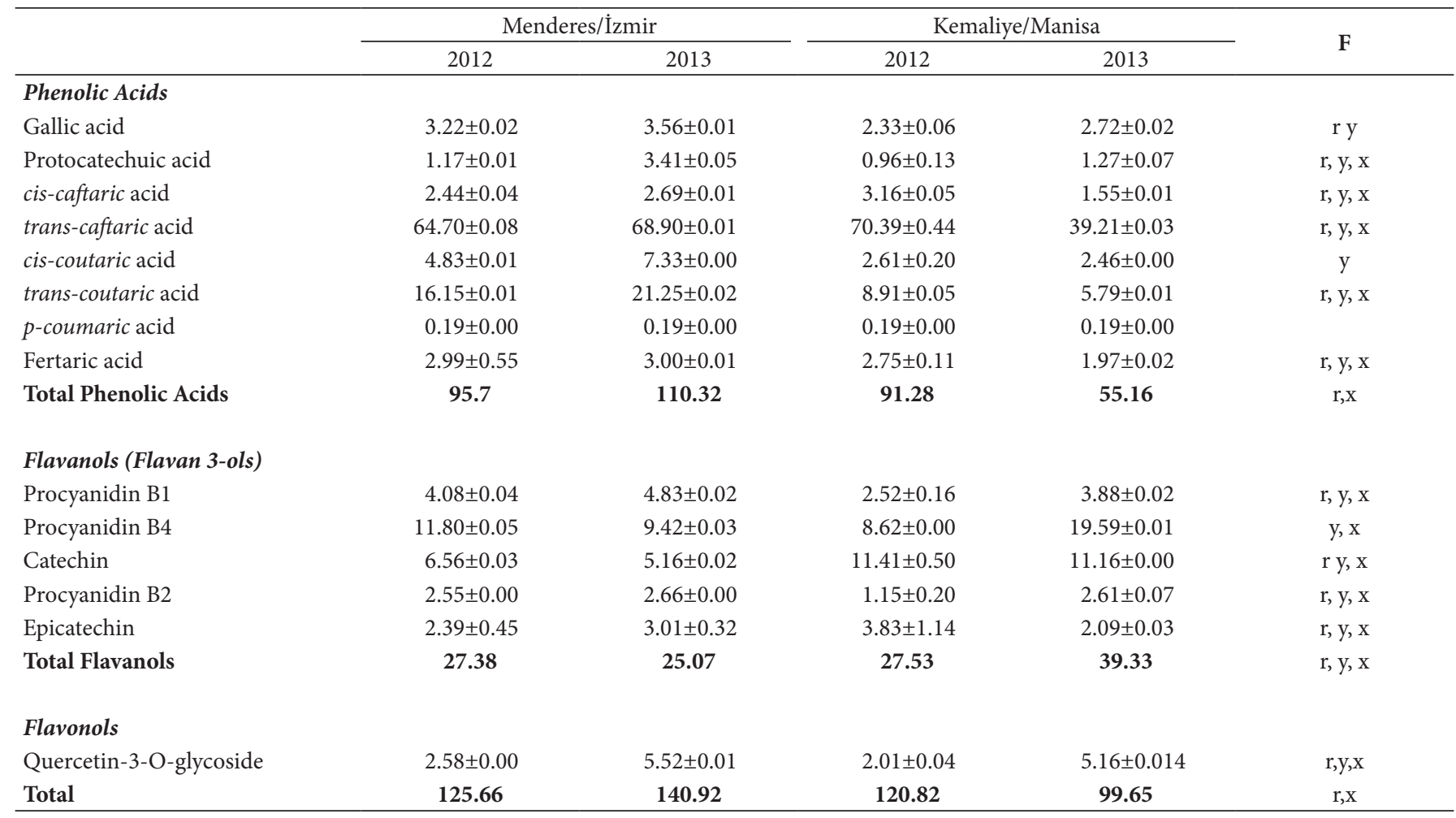

Multivariate Analysis of Variance was applied to the samples. r: regional difference, $y$ : difference in years, $\mathrm{x}$ : difference in terms of region and year.

and as phenolic acids) than wines from the Kemaliye region for both vintages. Statistically, concerning the terroirs, significantly different mean values were found for most of the phenolic compounds in the wines, except for cis-coutaric and p-coumaric acid. Trans-caftaric and trans-coutaric acids were the most abundant phenolic compounds, and these total phenolic acids were statistically no different by year. These two compounds are tartaric acid esters of hydroxycinnamic acids, and they are the main phenol class of must and wine. They act as oxidases and initiate the browning reactions.

Similar to this study, Sen \& Tokatli (2014) also reported that Muscat white wines could be distinguished from other white wines with a higher hydroxycinnamic acid content. Likewise in their research, Lampir \& Pavlousek (2013) reported caftaric acid as the most dominant phenolic compound in Moravian Muscat wine $(37 \mathrm{mg} / \mathrm{L})$, followed by p-coutaric acid $(14 \mathrm{mg} / \mathrm{L})$. They also reported that the average content of these compounds was much lower in Perna, a site which is comprised of geological limestone bedrock $(8 \mathrm{mg} / \mathrm{L}$ and $3 \mathrm{mg} / \mathrm{L}$, respectively). In this study, Kemaliye, which has a lime-rich soil type vineyard, there were lower amounts of caftaric acids in the wine of the 2013 vintages, but not in the 2012 vintage. The average caftaric acid content of different white wines has been reported to range from 8 to $54 \mathrm{mg} / \mathrm{L}$.

Procyanidin B4 was the most abundant flavanol in both terroirs. Higher flavanol content, especially procyanidin B4, was found in the Kemaliye wines. Proanthocyanidins located in grape seeds are responsible for the astringency and bitterness of wine (Monagas et al., 2005).
Flavonols are mainly located on the surface of the grape skin, and they strongly absorb light at a wavelength of $360 \mathrm{~nm}$, like a natural sunscreen. It has been reported that light increases the amount of flavonols (Price et al., 1995). Due to the production style of the white wines, flavonols are present in relatively smaller amounts in Muscat of Bornova wines compared to red wine varieties.

The most important hydroxybenzoic acids in grapes are gallic and protocatechuic acids (Rentzsch et al., 2009). Gallic and protocatechuic acids normally range between 2.33 to $3.56 \mathrm{mg} / \mathrm{L}$ and 0.96 to $3.41 \mathrm{mg} / \mathrm{L}$, respectively. Compared to Muscat of Bornova wines, Lampir \& Pavlousek (2013) reported that gallic and protocatechuic acid concentrations were lower at 1.2 and $1.4 \mathrm{mg} / \mathrm{L}$ in Moravian Muscat wine, respectively. Catechin is one of the major flavan-3-ol monomers found in grapes and wines, and the concentration of catechin was found to be from 5.16 to $11.41 \mathrm{mg} / \mathrm{L}$ in Muscat of Bornova wines. The Kemaliye terroir wines had a higher value than the Menderes terroir wines for both years. In white wines, catechin is reported as ranged from 7.4 to $10.6 \mathrm{mg} / \mathrm{L}$ (Lampir \& Pavlousek, 2013).

The lighter soil color of Kemaliye, which is also related to its high lime levels, lets more light get to the grape clusters and this can be related to higher flavonol amounts in the Kemaliye terroir. The Principal Component Analysis of phenolic compounds of Muscat of Bornova wines is shown in Figure 3. Catechin seems to have a relationship to Kemaliye wines for both years and have an antagonistic relationship with gallic, and cis and trans-coutaric acids that have a relationship with the Menderes region wines. When it is compared with regional meteorological 


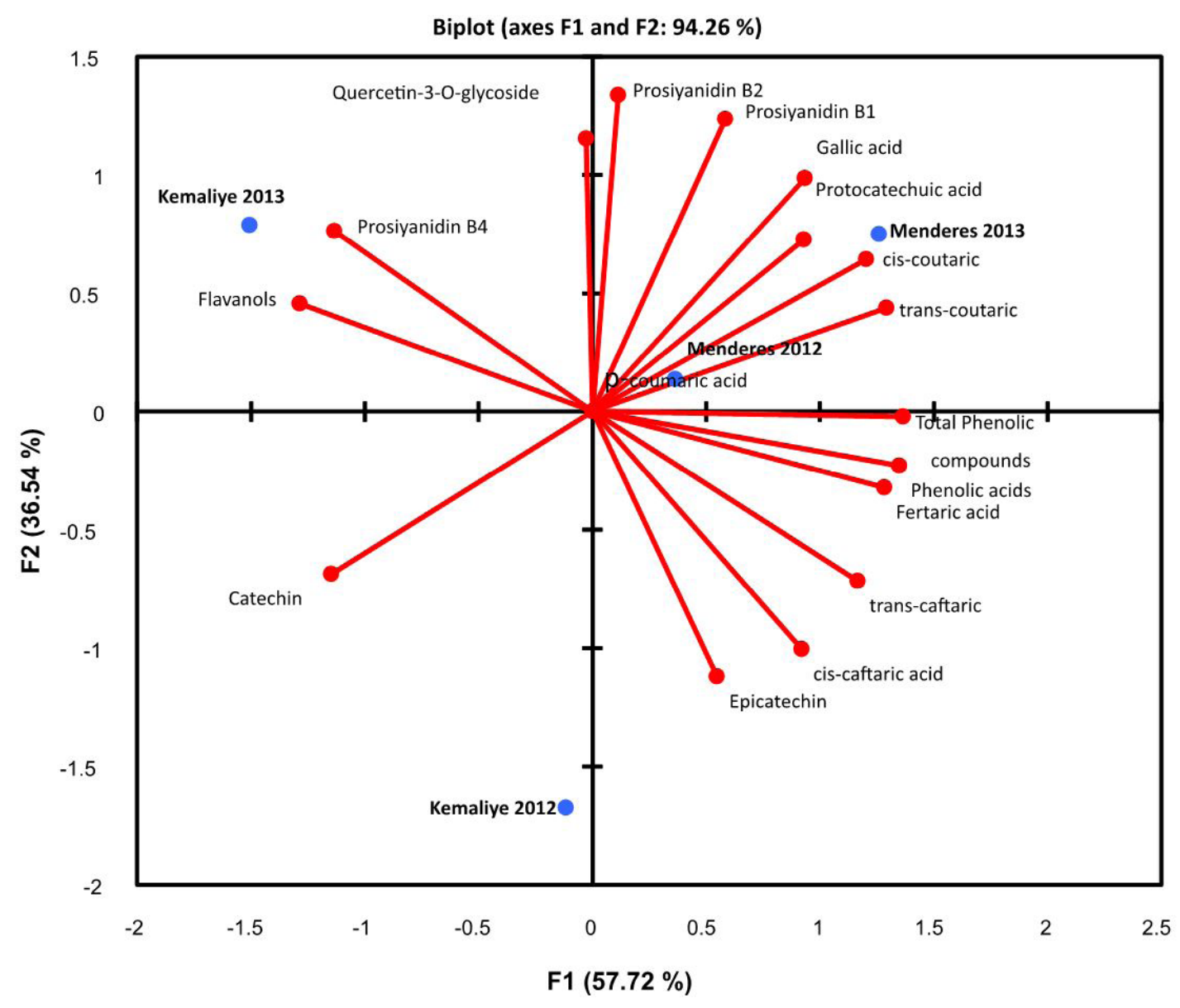

Figure 3. Principal component analysis of phenolic compounds of Muscat of Bornova wines.

data, annual rainfall and temperatures $\left(\mathrm{T}_{\max }, \mathrm{T}_{\min }\right.$, and $\left.\mathrm{T}_{\mathrm{avg}}\right)$ were higher in the 2013 vintages in both terroirs. In relation to this, gallic acid, protocatechuic acid, procyanidin B1, procyanidin $\mathrm{B} 2$, Quercetin-3-o-glucoside contents were higher in the second year samples from the terroirs, which could be related to the higher temperatures and higher berry evapotranspiration (Van Leeuwen \& Darriet, 2016).

Statistically, these compounds were affected by both vintage and terroir. However, the effect of vintage seems more influential. Also, in the Kemaliye terroir 2013 vintage, some unexpected rainfalls were reported that could be related to some dramatic differences, such as the amount of trans-coutaric acid and procyanidin B4. The factors that affect the composition are not limited to the rainfall or temperature parameters. There could be some other factors that could not be determined in this study, like changing solar radiation, vapor pressure deficit or winds.

\section{Conclusion}

In this two-year research, the terroir and vintage effects on the composition of Muscat of Bornova wines were investigated. Wines from the Menderes terroir have a slightly higher amount of phenolic compounds (as a total and as phenolic acids) than wines from the Kemaliye region for both vintages. In terms of aromatic compounds, terpenes were found to be the most important group in Muscat of Bornova wine and were higher in 2013 for both terroirs. In relation to regional meteorological data, the annual rainfall and temperatures (Tmin, Tmax and Tavg) were higher in the 2013 vintages for both terroirs, which could have affected the total number of terpenes. Furthermore, in the 2013 June to July period there were some unexpected rains during berry development in the Kemaliye terroir. With regard to that, phenolic compounds can be affected, and gallic acid, protocatechuic acid, procyanidin B1, procyanidin B2 and Quercetin-3-O-glucoside were higher in the second-year samples from the terroirs. Also, in the Kemaliye terroir 2013 vintage, there were some dramatic differences, such as the amount of trans-coutaric acid (a decline) and procyanidin B4 (an increase). According to the results, most of the compounds were statistically affected by both vintage and terroir, but the effect of vintage seems more influential.

\section{Acknowledgements}

The authors would like to thank the Çukurova University Scientific Research Projects Unit (Project Number: ZF2012 D.13) and The Scientific and Technical Research Council of Turkey (TUBITAK-Project No. 112O832) for their financial support of this research and the Kavaklidere Wine Company for providing samples. 


\section{References}

Boidron, J. (1978). Relation entre les substances terpéniques et la qualité du raisin (Role du Botrytis cinerea). Annales de Technologie Agricole. 27(1), 141-145.

Bordiga, M., Rinaldi, M., Locatelli, M., Piana, G., Travaglia, F., Coisson, J. D., \& Arlorio, M. (2013). Characterization of Muscat wines aroma evolution using comprehensive gas chromatography followed by a postanalytic approach to 2D contour plots comparison. Food Chemistry, 140(1-2), 57-67. http://dx.doi.org/10.1016/j.foodchem.2013.02.051. PMid:23578615.

Bouyoucos, G. J. (1962). Hydrometer method improved for making particle size analyses of soils. Agronomy Journal, 54(5), 464-465. http://dx.doi.org/10.2134/agronj1962.00021962005400050028x.

Campo, E., Ferreira, V., Escudero, A., \& Cacho, J. (2005). Prediction of the wine sensory properties related to grape variety from dynamicheadspace gas chromatography-olfactometry data. Journal of Agricultural and Food Chemistry, 53(14), 5682-5690. http://dx.doi. org/10.1021/jf047870a. PMid:15998133.

Celik, Z. D., Karaoglan, S. Y., Darıcı, M., Kelebek, H., İşçi, B., Kaçar, E., \& Cabaroglu, T. (2015). Effects of terroir on the terpene compounds of Muscat of Bornova Native white grape variety grown in Turkey. BIO Web of Conferences, 5(01004), 1-7. http://dx.doi.org/10.1051/ bioconf/20150501004.

Del Caro, A., Fanara, C., Genovese, A., Moio, L., Piga, A., \& Piombino, P. (2012). Free and enzymatically hydrolysed volatile compounds of sweet wines from Malvasia and Muscat grapes (Vitis vinifera L.) grown in Sardinia. South African Journal of Enology and Viticulture, 33(1), 115-121.

Delcroix, A., Günata, Z., Sapis, J.-C., Salmon, J.-M., \& Bayonove, C. (1994). Glycosidase activities of three enological yeast strains during winemaking: Effect on the terpenol content of Muscat wine. American Journal of Enology and Viticulture, 45(3), 291-296.

Ferreira, V., Lopez, R., \& Cacho, J. F. (2000). Quantitative determination of the odorants of young red wines from different grape varieties. Journal of the Science of Food and Agriculture, 80(11), 1659-1667. http://dx.doi.org/10.1002/1097-0010(20000901)80:11<1659::AIDJSFA693>3.0.CO;2-6.

Fukuda, K., Watanabe, M., Asano, K., \& Ohta, S. (1990). Mutants of yeast Saccharomyces cerevisiae producing large amounts of the flavor components isobutyl alcohol and isoamyl alcohol. Agricultural and Biological Chemistry, 54(9), 2445-2446. http://dx.doi.org/10.1271/ bbb1961.54.2445.

Guth, H. (1997). Quantitation and sensory studies of character impact odorants of different white wine varieties. Journal of Agricultural and Food Chemistry, 45(8), 3027-3032. http://dx.doi.org/10.1021/ jf970280a.

International Organisation of Vine and Wine - OIV. (2016). Compendium of international methods of wine and must analysis. Paris, France: International Organisation of Vine and Wine.

Jackson, D., \& Lombard, P. (1993). Environmental and management practices affecting grape composition and wine quality-a review. American Journal of Enology and Viticulture, 44(4), 409-430.

Kelebek, H., Canbas, A., Jourdes, M., \& Teissedre, P. L. (2011). HPLC-DAD-MS determination of colored and colorless phenolic compounds in Kalecik Karasi Wines: Effect of different vineyard locations. Analytical Letters, 44(6), 991-1008.

Lampir, L., \& Pavlousek, P. (2013). Influence of locality on content of phenolic compounds in white wines. Czech Journal of Food Sciences, 31(6), 619-626. http://dx.doi.org/10.17221/337/2013-CJFS.
Lindsay, W. L., \& Norvell, W. A. (1978). Development of a DTPA soil test for zinc, iron, manganese, and copper. Soil Science Society of America Journal, 42(3), 421-428. http://dx.doi.org/10.2136/sssaj19 78.03615995004200030009x.

McGuire, R. G. (1992). Reporting of objective color measurements. HortScience, 27(12), 1254-1255. http://dx.doi.org/10.21273/ HORTSCI.27.12.1254.

Monagas, M., Bartolome, B., \& Gomez-Cordoves, C. (2005). Updated knowledge about the presence of phenolic compounds in wine. Critical Reviews in Food Science and Nutrition, 45(2), 85-118. http:// dx.doi.org/10.1080/10408690490911710. PMid:15941014.

Nykänen, L., \& Suomalainen, H. (1983). O-Heterocyclic compound in: Aroma of beer, wine and distilled alcoholic beverages. Boston: D. Reidel Publishing Company.

Olsen, S., \& Sommers, L. (1982). Phosphorus. In A. L. Page, R. H. Miller \& D. R Keeney. Methods of soil analysis Part 2. Chemical and Microbiolgial Properties, Agronomy Monograph. Madison, Wisconsin: American Society of Agronomy, Soil Science Society of America.

Ough, C. S., \& Amerine, M. A. (1988). Methods for analysis of musts and wines (2nd ed.). New York: John Willey and Sons.

Price, S. F., Breen, P. J., Valladao, M., \& Watson, B. T. (1995). Cluster sun exposure and quercetin in pinot noir grapes and wine. American Journal of Enology and Viticulture, 46(2), 187-194.

Provenzano, M. R., El Bilali, H., Simeone, V., Baser, N., Mondelli, D., \& Cesari, G. (2010). Copper contents in grapes and wines from a Mediterranean organic vineyard. Food Chemistry, 122(4), 1338-1343. http://dx.doi.org/10.1016/j.foodchem.2010.03.103.

Radeka, S., Herjavec, S., Persuric, D., Lukic, I., \& Sladonja, B. (2008). Effect of different maceration treatments on free and bound varietal aroma compounds in wine of Vitis vinifera L. cv. Malvazlia istarska bijela. Food Technology and Biotechnology, 46(1), 86-92.

Rentzsch, M., Wilkens, A., \& Winterhalter, P. (2009). Non-flavonoid phenolic compounds. In M. Victoria Moreno-Arribas \& M. Carmen Polo. Wine chemistry and biochemistry (pp. 509-527). New York: Springer. http://dx.doi.org/10.1007/978-0-387-74118-5_23.

Ribéreau-Gayon, P., Glories, Y., Maujean, A., \& Dubourdieu, D. (2006). Varietal aroma. In P. Ribéreau-Gayon, Y. Glories, A. Maujean \& D. Dubourdieu. Handbook of enology (pp. 205-230). Chichester: John Wiley \& Sons, Ltd. http://dx.doi.org/10.1002/0470010398.ch7.

Seguin, G. (1986). 'Terroirs' and pedology of wine growing. Experientia, 42(8), 861-873. http://dx.doi.org/10.1007/BF01941763.

Seguin, G. (1988). Ecosystems of the great red wines produced in the maritime climate of Bordeaux. In L. Fuller-Perrine (Ed.), Proceedings Symposium on Maritime Climate Winegrowing. Geneva, NY: Department of Horticultural Sciences, Cornell University.

Selli, S., Canbas, A., Cabaroglu, T., Erten, H., \& Gunata, Z. (2006). Aroma components of cv. Muscat of Bornova wines and influence of skin contact treatment. Food Chemistry, 94(3), 319-326. http:// dx.doi.org/10.1016/j.foodchem.2004.11.019.

Sen, I., \& Tokatli, F. (2014). Characterization and classification of turkish wines based on elemental composition. American Journal of Enology and Viticulture, 65(1), 134-142. http://dx.doi.org/10.5344/ ajev.2013.13081.

Simpson, R. (1979). Some important aroma components of white wine. Food Technology in Australia, 31, 516-522.

Strauss, C., Wilson, B., \& Williams, P. (1986, July 14-17). Flavour of non-Muscat varieties. In T. Lee. Proceedings 6th Australian Wine Industry Technical Conference (pp. 117-120). Adelaide: Australian Industrial Publishers. 
Styger, G., Prior, B., \& Bauer, F. (2011). Wine flavor and aroma. Journal of Industrial Microbiology \& Biotechnology, 38(9), 1145-1159. http:// dx.doi.org/10.1007/s10295-011-1018-4. PMid:21786136.

Van Leeuwen, C., \& Darriet, P. (2016). The impact of climate change on viticulture and wine quality. Journal of Wine Economics, 11(1), 150-167. http://dx.doi.org/10.1017/jwe.2015.21.

Van Leeuwen, C., Roby, J.-P., Pernet, D., \& Bois, B. (2010). Methodology of soil-based zoning for viticultural terroirs. Bulletin de l'O.I.V., 83(947), 13-29.

Varnam, A., \& Sutherland, J. (1994). Beverages: Technology, chemistry and microbiology (Vol. 2). New York: Springer Science \& Business Media. http://dx.doi.org/10.1007/978-1-4615-2508-0.
Vilanova, M., Zamuz, S., Vilarino, F., \& Sieiro, C. (2007). Effect of terroir on the volatiles of Vitis vinifera cv. Albarino. Journal of the Science of Food and Agriculture, 87(7), 1252-1256. http://dx.doi. org/10.1002/jsfa.2833.

Wang, R., Sun, Q., \& Chang, Q. R. (2015). Soil types effect on grape and wine composition in Helan Mountain Area of Ningxia. Plos One, 10(2), 1-12.

White, R., Balachandra, L., Edis, R., \& Chen, D. (2007). The soil component of terroir. Journal International des Sciences de la Vigne et $d u$ Vin, 41(1), 9.

Wyszecki, G., \& Stiles, W. S. (1982). Color science (Vol. 8). New York: Wiley. 


\section{Supplementary Material}

Supplementary material accompanies this paper.

Supplemental File 1. General and Meteorological Properties of studied vineyards.

Supplemental File 2. General composition and properties of the studied Muscat of Bornova vineyard soils.

Supplemental File 3. Volatile compounds of Muscat of Bornova wines from all terroirs in 2012, 2013 vintages ( $\mu \mathrm{g} / \mathrm{L}$ ).

This material is available as part of the online article from http://www.scielo.br/CTA 